\title{
Assessment and Introspection of Gifted Programming of USA: From the Perspective of Industrialization of Education of Giftedness and Practice of Gifted Education Teachers
}

\author{
Songzhu Mei ${ }^{1}$, Zhengxin Zhu ${ }^{2}$, Ping Leng ${ }^{3 *}$ \\ ${ }^{1}$ Educational College, Huaibei Normal University, Huaibei Anhui, China \\ ${ }^{2}$ School of Language and Culture, Shanghai Normal University Tianhua College, Shanghai, China \\ ${ }^{3}$ College of Mathematic and Science, Huaibei Normal University, Huaibei Anhui 235000, China
}

*Corresponding Author.

\begin{abstract}
For a long time, the U.S. government has paid great attention to gifted education, issued many educational acts and standardized about gifted education, which provides high effect in the fields of theory, model and practice of gifted education. From the perspective of industrialization of Education of giftedness and practice of gifted education teachers, six aspects of standards are analyzed, including studying and development, identification and evaluation, curriculum and teaching, learning environment, project implementation and professional development of gifted education teachers. Combining the actual conditions of gifted education in China, several enlightenment could be drawn as setting goals by educational outputs, adhering to fair principle, paying attention to growth environment, focusing on professional development, perfecting the systems of evaluation and supporting gifted programming for expecting long-term returns.
\end{abstract}

Keywords: giftedness; gifted education; industrialization; gifted programming; standard; educational fairness

\section{Introduction}

Gifted individuals are the core motivity and scarce resources of a nation's development. The quality and quantity of the gifted group determine innovation capability and international competitiveness of a country to a large extent. In the era of globalization, gifted education has attracted increasing number of countries' attention. The United States, acting as the pioneer, has accumulated rich theoretical and practical experience in gifted education programs, which offers important reference functions for the development of gifted education in China.

\section{Brief Introduction of American gifted education}

\subsection{Intension of giftedness}

Giftedness, also known as gifted and talented, is a group concept, which usually refers to a group of people who have exceeding ability and extraordinary achievements in intelligence, capacities, etc. Such people generally show advancing development of thinking, powerful ability of judgment and inference, outstanding academic achievements, supernormal cognition and emotion, or have special talents or capability in specific fields. No Child Left Behind Act in the United States defines gifted people as children, students, or young adults, who are proved by evidence, possessing extremely high achievements in intelligence, creativity, aesthetic, leadership or specific academic fields. Under Chinese context, gifted people could be referred to as "talents favored by god", "wander children", "skilled talents", "excellent talents", or labeled as "precocious", "owing outstanding aptitudes", "brilliant", "supernormal", "extraordinary", etc.

To comprehend giftedness, we could operate from six aspects, including talent, capability, motivation, environment, learning and practice. ${ }^{[1]}$ Talent is the essence of giftedness, a ternary structure constructed by intelligence, ISSN: 0010-8189 
motivation and creativity, which emphasizes creating breakthrough, curiousness and diligent thinking, smart and sharp, unimpeded communication, scientific predicting, decisive, reasonable planning, effective operating, interpersonal communicating, exploring and practicing. ${ }^{[2]}$ Compared with peers, children possessing some kinds of talents are usually earlier and faster to enter specific fields. They have strong learning motivation, outstanding concentration and unique learning styles. To understand giftedness, we should correctly view the interrelationship between heredity, intelligence and talents. Although most people approve genetic factors influence intellectual development of individuals to a large extent, ${ }^{[3]}$ and intelligence is frequently applied to judge talents, developmental research on giftedness is not supposed to hesitate on whether talents acquired from nature or nurture. On the contrary, such research concentrates on the interaction effects between genetic inheritance and social and cultural environment. In order to study giftedness, except following specific social regulations or moral principles, three common mistakes should be prevented, including empirical prejudice, unclear ontological identity and the shortage of internal theoretical standards constituted by philosophy of science. ${ }^{[4]}$

\subsection{History of gifted education in the United States}

In 1920s, with the rapid development of pedagogy and psychology, empiricism and scientific positivism occupied the mainstream status. Accompanying with IQ test, giftedness of modern significance started to bud. In 1957, the Soviet Union's satellite was launched successfully shocked the whole United States. After imputing the lack of gifted force, US government promoted gifted education to the height of national strategy. In 1972, Marland Report officially defined the concept of giftedness for the first time. In 1974, US Ministry of Education (MOE) established the Office of Gifted Education to cultivate the educational program. In 1983, A Nation at Risk Act declared that there existed severe shortage in the education and service for gifted group. In 1988, Jacob K.Javits Gifted and Talented Education Act was published, which reemphasized the importance of gifted education. In 1990, National Research Center on the Gifted and Talented (NRC/GT) was established, which set up gifted education research institutes in the University of Connecticut, University of Virginia, University of Georgia and Yale University. In 1993, National Excellence: The Case for Developing America's Talent was published by MOE to restate the situation of improper ignorance of gifted education. In 1998, National Association for Gifted Children (NAGC) proclaimed K12 gifted education program standards. In 2002, Javits Act started to fund gifted education programs. In 2004, Belin-Blank Center, University of Lowa launched A Nation Deceived: How Schools Hold Back American Brightest Students, which disclosed the accelerating strategies and equity issues. NAGC published National Standards in Gifted and Talented Education in 2006 and amended in 2013. Since then, gifted education in the United States is gradually perfected and systematic in policy, system, financial support, protection, and research and has become the paradigm for other countries around the world.

\subsection{Studies on gifted education}

Research on American gifted education involves a large range of content, including connotation characteristics, theoretical frameworks, practical models, philosophical foundations, ethical issues, emphasizing the exploration on the interaction among heredity, motivations, passions, experience, surroundings, and mindfulness ${ }^{[5]}$, trying to find specific teaching strategies and parenting styles of gifted education to reveal the possible approaches to help gifted children putting to good use of their potentials and going beyond themselves. The research objects are mainly the children who have extraordinary cognitive competence and academic achievements, as well as the ones with IQ over 160. ${ }^{[6]}$ Through systematic evaluation procedures, gifted children are selected and cultivated according to their personalized needs, so that their potential and talents could be dug out. On the one hand, gifted education focus on the transferring, continuing and realizing of talent, and gifted children's learning potentials are evaluated through dynamic interactive approaches ${ }^{[7]}$; on the other hand, attention is drawn on policy, protection and evaluation to prevent their unique interests and abilities from vanishing under improper surroundings or supports. ${ }^{[8]}$

Cultivating mode of American gifted education includes acceleration, enrichment and grouping. Typical programs contain Purdue Model and Kaplan grid model which have provided generalized and curriculum designing frameworks for gifted education. ${ }^{[9]}$ Concrete programs are mainly committed by universities. For instance,

ISSN: 0010-8189 
University of Connecticut is responsible for mathematic research on gifted education, while University of Virginia (UVA) takes the charge of language related studies. They have made jointed efforts in developing teaching instruction models, depth and complexity models, school enriching models and, STEM (Science, Technology, Engineering, and Mathematics Schools of Excellence) education program. By using, STEM matrix, gifted education teachers are selected and interviewed as the foundation of further research. ${ }^{[10]}$ In addition, Stanford University exploited Malleable Minds Project to study the best performance of gifted children under psychology and neurosciences. Status of Gifted Education Programming, launched by UVA, evaluated the institutional authorization, educational appropriation, teaching qualification, project appraisal, etc.

In order to guarantee the implement of gifted education, the United States established a number of non-profit organizations and research institutions, such as National Association for Gifted Children, the Association for the Gifted, Supporting the Emotional Needs of the Gifted, Center for Gifted Education Policy, Teachers and Parents for Bright Children, and research centers in some universities. Every state also provides specific schools or classes to support gifted education.

\section{Six Standards of Gifted Education Programs}

From the beginning of gifted education, disputes have never stopped. The focal points include whether the so-called gifted children are real "talents"; whether the policies are democratic, sufficient, equal and necessary enough; whether gifted education serves specific political purpose. ${ }^{[11]}$ In order to eliminate above doubts, regulate the process of authentication, selection, cultivation, and the design, exploitation and evaluation, and strengthen the confidence of the whole country, high quality gifted education standard was born at the right moment. In 2006, National Standards in Gifted and Talented Education was published. The Standards focuses on high-quality gifted education programs and services, and judges through the educational output (not the final achievements at that time), providing basics for policy, regulations and procedures of gifted education. During the implementation of the Standards, teachers, who might be gifted person as well, have much profound feelings for their close and long-term contact with gifted children. These teachers' understanding and using of the Standards, as well as the professional literacy of themselves will directly influence the implementation effect of gifted education practice. The following six standards have been set to explore the quality of gifted education programs and services, and motivate the educational output based on the career preparation and practical ability of gifted education teachers.

\subsection{Learning and developmental standards}

Learning and development of gifted children are expressed in three aspects, including self-understanding, demanding consciousness, and cognitions and emotions. Gifted education teachers should not only fully comprehend the features, demands and variation of cognition and emotions, but also be aware of their difference in learning and development, and then plan the curriculum, instruction, evaluation, projects and service on purpose, so that gifted children could tap their potentials.

Table 1 Learning and developmental standards of gifted education

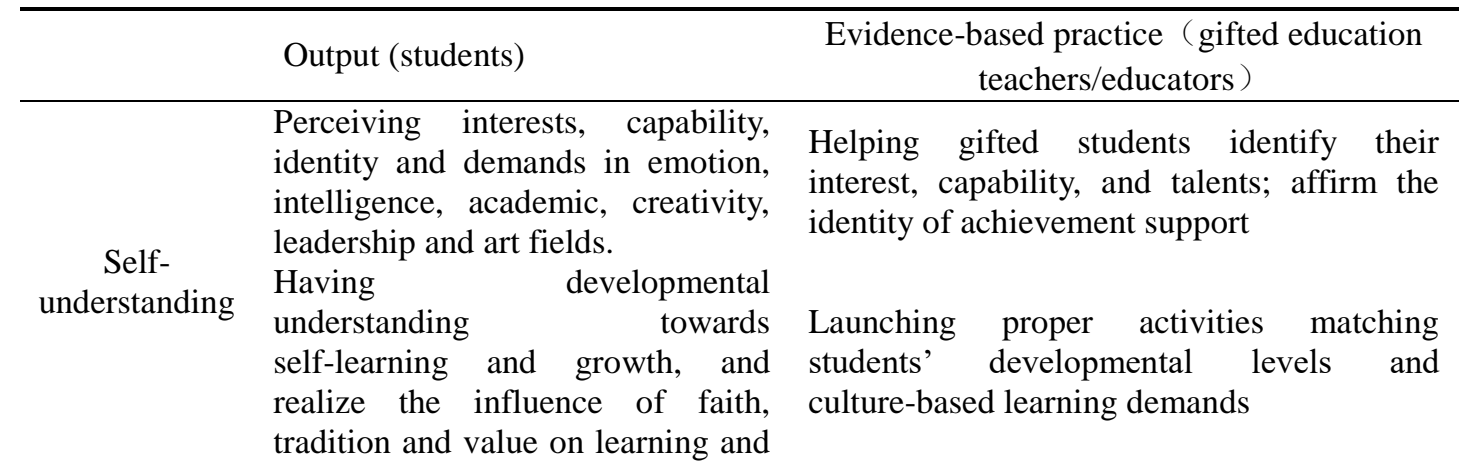

ISSN: 0010-8189 


\begin{tabular}{|c|c|c|}
\hline & $\begin{array}{l}\text { behaviors. } \\
\text { Comprehending the similarities and } \\
\text { differences between ordinary peers } \\
\text { and themselves, as well as other } \\
\text { gifted peers. }\end{array}$ & $\begin{array}{l}\text { Providing group practices to give them } \\
\text { interactive chances with other kinds of gifted } \\
\text { students. }\end{array}$ \\
\hline \multirow[t]{2}{*}{$\begin{array}{l}\text { Demanding } \\
\text { consciousness }\end{array}$} & $\begin{array}{l}\text { Getting resources from } \\
\text { communities to support their } \\
\text { cognitive and emotional demands. }\end{array}$ & $\begin{array}{l}\text { Through mentor or bibliotherapy to construct } \\
\text { models matching their capabilities and } \\
\text { interests; being able to identify after school } \\
\text { learning chances suiting their capabilities } \\
\text { and interests. }\end{array}$ \\
\hline & $\begin{array}{l}\text { Realizing family could fully } \\
\text { understand personal features and } \\
\text { demands. }\end{array}$ & $\begin{array}{l}\text { Helping family to acquire resources } \\
\text { exploiting children's talents. }\end{array}$ \\
\hline \multirow{3}{*}{$\begin{array}{l}\text { Cognitions \& } \\
\text { emotions }\end{array}$} & $\begin{array}{l}\text { From challenging learning } \\
\text { activities to obtain benefits from } \\
\text { cognitions and emotions. }\end{array}$ & $\begin{array}{l}\text { Designing interventional strategies } \\
\text { promote their cognitions and emotions. }\end{array}$ \\
\hline & $\begin{array}{l}\text { Realizing their preferred learning } \\
\text { styles. }\end{array}$ & $\begin{array}{l}\text { Helping them to judge their preferred } \\
\text { learning styles and adjust and strengthen this } \\
\text { pattern. }\end{array}$ \\
\hline & $\begin{array}{l}\text { Ensuring future career targets } \\
\text { based on their own talents. }\end{array}$ & $\begin{array}{l}\text { Offering universities positions or vocational } \\
\text { guidance to gifted students. }\end{array}$ \\
\hline
\end{tabular}

\subsection{Evaluation criteria}

Gifted persons identification means authenticating their gifted identity and learning process. Gifted education teachers should build challenging environment and collect assessing information from various perspectives. At the same time, authenticating approaches should be impartial, equal and technically sufficient. By combining performance assessment and appraisal, gifted individuals could be screened out from different backgrounds. Based on above steps, operating elements in gifted education programs could be adjusted and optimized.

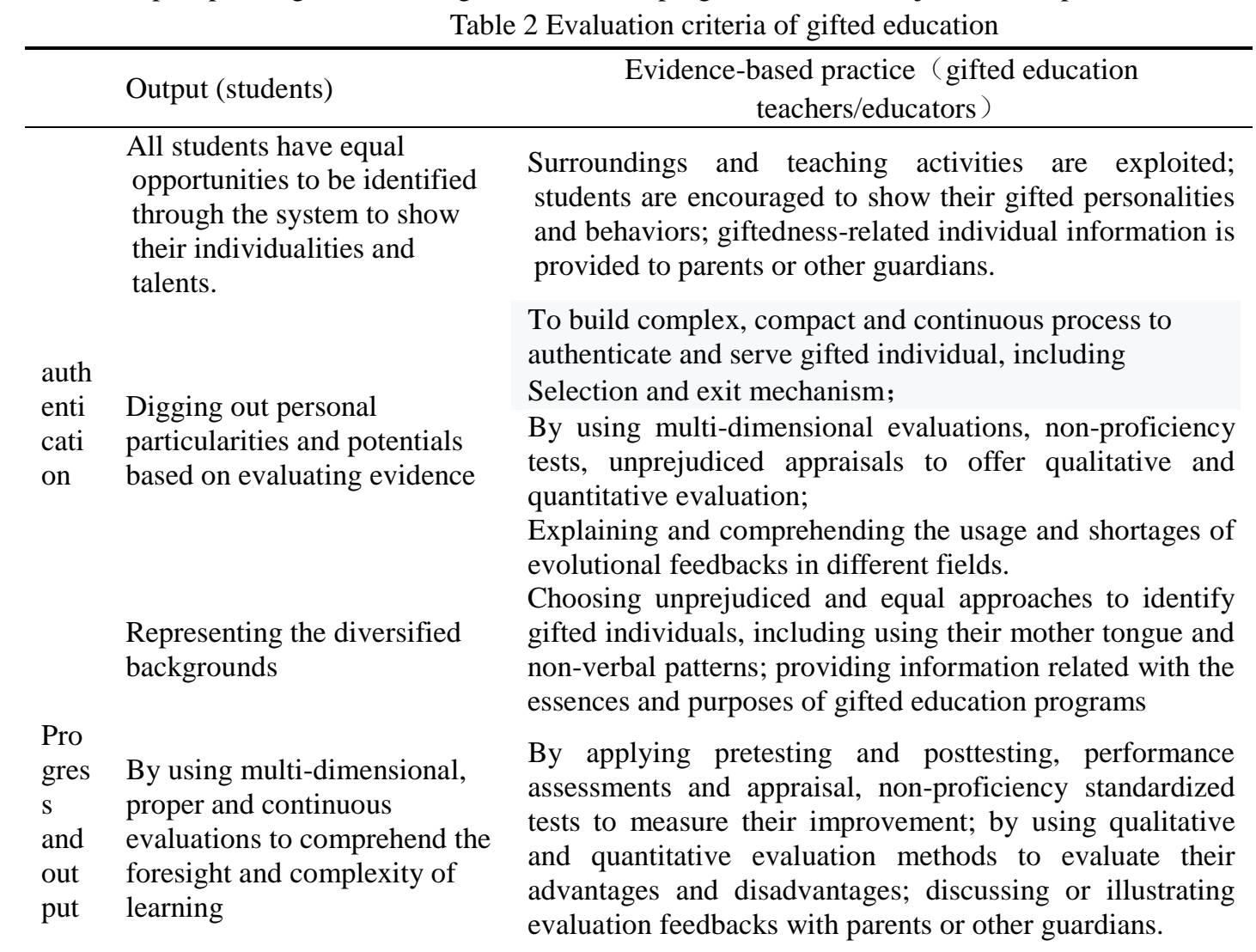




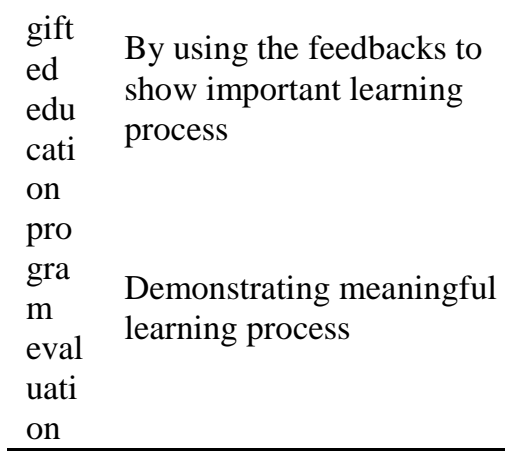

To ensure relatively high reliability and validity of the evaluations; to measure acquisition of knowledge, advanced thoughts, achievements in specific fields and emotional development through multi-representations

Offering necessary time and resources to formulate and operate annual evaluating plans; analyzing the influence factors of achievement output *; propagandizing the results of evaluation orally or in writing and explain how to use them

*Note: Factors contains authentication, curriculum, teaching \& services, learning evaluation, consulting and guidance, gifted education teachers' development, parents/guardians and communities, project resources, and the design, management and delivery of projects.

\subsection{Curriculum and teaching standards}

Curriculum planning and teaching of gifted education contains curriculum contents, teaching strategies, teaching resources and other aspects. Teachers of gifted education apply integrated, serial core courses to achieve the consistency with local, state and national standards, while obtaining distinctions and expansions in some degree. In order to meet the demands of gifted students, curriculum should emphasize the features, depth, complexity, advancement, and the challenges of concepts in cognition, emotion, aesthetic, society, leadership, and etc. Teachers should apply evidence-based teaching strategies to develop students' talents, reinforce learning, and provide necessary knowledge and skills to cultivate students into independent and self-conscious learners. At the same time, teachers should also instruct them how to use tools, so that they could make contributions for the multicultural and diverse society.

Table 3 Curriculum and teaching standards of gifted education

\begin{tabular}{|c|c|c|}
\hline & Output (students) & Evidence-based practice (gifted education teachers/educators) \\
\hline $\begin{array}{l}\text { Curriculum } \\
\text { planning }\end{array}$ & $\begin{array}{l}\text { Demonstrating } \\
\text { giftedness relevant } \\
\text { growth }\end{array}$ & $\begin{array}{l}\text { Adopting, amending core curriculum standards to meet students' specia } \\
\text { needs; applying integrated, continuous and discrete curriculum } \\
\text { planning; designing and adjusting progressive, concept-challenging } \\
\text { profound, distinctive, complex and distinguishing curriculum }\end{array}$ \\
\hline \multirow{2}{*}{$\begin{array}{l}\text { Giftedness } \\
\text { development }\end{array}$} & $\begin{array}{l}\text { Being more } \\
\text { competitive in gifted } \\
\text { fields }\end{array}$ & $\begin{array}{l}\text { Designing challenging and efficient curriculum in cognition, emotion } \\
\text { aesthetic, society, leadership, and etc.; applying met-cognitive models } \\
\text { to meet gifted students' needs. }\end{array}$ \\
\hline & $\begin{array}{l}\text { Developing abilities } \\
\text { in talents/interests }\end{array}$ & $\begin{array}{l}\text { resources to face the diversity of gifted students; using school and } \\
\text { community resources to support their diversity; providing chances to } \\
\text { exploit, develop and study their talents/interests }\end{array}$ \\
\hline $\begin{array}{l}\text { Teaching } \\
\text { strategies }\end{array}$ & $\begin{array}{l}\text { Serve as independent } \\
\text { investigators }\end{array}$ & $\begin{array}{l}\text { Using models in critical thinking, creative thinking, problem solving } \\
\text { and strategic consulting to meet their needs }\end{array}$ \\
\hline Curriculum & $\begin{array}{l}\text { Developing } \\
\text { knowledge and skills } \\
\text { in a multi-cultural, } \\
\text { diversified, and } \\
\text { globalized society }\end{array}$ & $\begin{array}{l}\text { Exploiting and using challenging and specific culture matched } \\
\text { curriculum; integrating career exploring experience, focusing on } \\
\text { bolographic learning and speech; applying curriculum to deepen the } \\
\text { diversity studies on culture, language and current affairs }\end{array}$ \\
\hline Resources & $\begin{array}{l}\text { Obtaining a amount } \\
\text { of high-quality } \\
\text { resources }\end{array}$ & Demonstrating familiar high-quality resources and materials \\
\hline
\end{tabular}

3.4 Learning environment standards 
Safe learning environment could cultivate fine emotional life, positive social interaction, leadership of dealing with social reforms, and cultural understanding on success under diverse society. Gifted education teachers should design a teaching environment, which could stimulate independence, motivation and self-efficacy of gifted individuals under different backgrounds. Such environment will let them understand the functions of language and communications profoundly, and make use of related strategies and techniques to promote the competitiveness in various aspects.

Table 4 Learning environment standards of gifted education

\begin{tabular}{|c|c|c|}
\hline & Output (students) & $\begin{array}{c}\text { Evidence-based practice ( gifted education } \\
\text { teachers/educators) }\end{array}$ \\
\hline $\begin{array}{l}\text { Individual } \\
\text { competitiveness }\end{array}$ & $\begin{array}{l}\text { Demonstrating individual } \\
\text { competitiveness, especially } \\
\text { academic competence and } \\
\text { creativity, including } \\
\text { self-awareness, self-defense, } \\
\text { self-efficiency, confidence, } \\
\text { motivation, elasticity, } \\
\text { independence, curiosity and } \\
\text { spirit of adventure }\end{array}$ & $\begin{array}{l}\text { In meaningful and challenging activities, gifted individuals } \\
\text { are endowed with relatively high expectations; through } \\
\text { mentors or role models, opportunities are provided for } \\
\text { gifted individuals on self-exploration, interest development, } \\
\text { achievement appraisal; creating an environment fully } \\
\text { trusting diverse learners; providing feedbacks and focusing } \\
\text { on individual efforts and evidence of potential to meet the } \\
\text { high evaluation standards; offering cases that positively } \\
\text { reply and use skills and chances }\end{array}$ \\
\hline $\begin{array}{l}\text { Social } \\
\text { competitiveness }\end{array}$ & $\begin{array}{l}\text { Demonstrating social } \\
\text { competitiveness and positive } \\
\text { peer relationships and social } \\
\text { intervention }\end{array}$ & $\begin{array}{l}\text { Understanding solo and social gifted individuals' needs; } \\
\text { providing chances of interacting with common peers, as } \\
\text { well as the ones with high IQ and creativity; providing } \\
\text { guidance on social skills in schools, communities and } \\
\text { workplaces }\end{array}$ \\
\hline Leadership & $\begin{array}{l}\text { Demonstrating individual and } \\
\text { social sense of duty and } \\
\text { leadership skills }\end{array}$ & $\begin{array}{l}\text { Creating safe, friendly surroundings to deal with social } \\
\text { issues and developing individual responsibility; creating } \\
\text { environments and opportunities of exploiting various kinds } \\
\text { of leadership capabilities and skills }\end{array}$ \\
\hline $\begin{array}{l}\text { Cultural } \\
\text { competitiveness }\end{array}$ & $\begin{array}{l}\text { Evaluating self and others' } \\
\text { language tradition inheritance } \\
\text { and circumstance; possessing } \\
\text { communication skills with multi } \\
\text { groups }\end{array}$ & $\begin{array}{l}\text { Constructing diverse backgrounds and multi-lingual } \\
\text { environmental and strategic models; accusing } \\
\text { discriminatory languages and behaviors; providing } \\
\text { structural chances to gifted individuals and diverse peers } \\
\text { under the shared purposes }\end{array}$ \\
\hline $\begin{array}{l}\text { Communicating } \\
\text { competitiveness }\end{array}$ & $\begin{array}{l}\text { Demonstrating competitiveness } \\
\text { in interpersonal } \\
\text { communication skills, oral and } \\
\text { writing expression, and other } \\
\text { kinds of communication skills }\end{array}$ & $\begin{array}{l}\text { Being aware of the diversity of cultural background among } \\
\text { students, and providing resources to promote their } \\
\text { expressing and communicating abilities; providing } \\
\text { advanced communication tools to express high-level } \\
\text { thoughts and creativities }\end{array}$ \\
\hline
\end{tabular}

\subsection{Executive standards of gifted education programs}

The execution of gifted education programs includes services, resources, policies and routes. Gifted education teachers could apply accelerating or enriching models to arrange groups and select and instruct individualized learning. This will improve gifted individuals' performance in the fields of cognition and emotion and help them set goals for their future career. Gifted education teachers should expand and integrate current technologies and provide more chance to students to gain high-level programs. In addition, teachers should also increase the connectivity between campus and after-school curriculum, while the cooperation with professional gifted education agencies, parents/guardians and communities should be built to meet the diverse needs of gifted individuals.

Table 5 Executive standards of gifted education programs

\begin{tabular}{lll}
\hline & Output (students) & Evidence-based practice (gifted education teachers/educators) \\
\hline \multirow{3}{*}{$\begin{array}{l}\text { Diversity of } \\
\text { programs }\end{array}$} & $\begin{array}{l}\text { Referring to various } \\
\text { evidence-based gifted }\end{array}$ & $\begin{array}{l}\text { Regularly using various approaches to accelerating learning, } \\
\text { enrichment models to expand or deepen learning chances, }\end{array}$ \\
& education programs, which & $\begin{array}{l}\text { various kinds of grouping (integration, resource classroom, } \\
\text { have improved the }\end{array}$ \\
special classes and special schools), and individualized
\end{tabular}

ISSN: 0010-8189 


\begin{tabular}{|c|c|c|}
\hline & $\begin{array}{l}\text { performance in cognition and } \\
\text { emotion }\end{array}$ & $\begin{array}{l}\text { learning options (tutorial system, probation, online courses and } \\
\text { independent learning; by impartially demonstrating resource } \\
\text { allocation and proven willingness, to ensure gifted individuals } \\
\text { gaining proper education service }\end{array}$ \\
\hline $\begin{array}{l}\text { Coordinating } \\
\text { services }\end{array}$ & $\begin{array}{l}\text { Through shared promises and } \\
\text { coordinating services to show } \\
\text { the progress }\end{array}$ & $\begin{array}{l}\text { Like educators in other special fields, launching gifted } \\
\text { education plan, development and implement in a cooperative } \\
\text { way }\end{array}$ \\
\hline Cooperation & $\begin{array}{l}\text { Regular cooperation with } \\
\text { families, communities and } \\
\text { schools }\end{array}$ & $\begin{array}{l}\text { Letting families and communities take part in programs } \\
\text { planning, operating, evaluating and suggesting }\end{array}$ \\
\hline Resources & $\begin{array}{l}\text { Obtaining sufficient financial } \\
\text { support }\end{array}$ & $\begin{array}{l}\text { Providing sufficient financial support for gifted education } \\
\text { programs and services }\end{array}$ \\
\hline Integration & $\begin{array}{l}\text { Developing potentials through } \\
\text { integrated and consistent } \\
\text { programs }\end{array}$ & $\begin{array}{l}\text { Exploiting considerate and long-term gifted education } \\
\text { programs }\end{array}$ \\
\hline Policies & $\begin{array}{l}\text { Guided by clear policies and } \\
\text { procedures }\end{array}$ & $\begin{array}{l}\text { Making policies and procedures based on evidence to guide } \\
\text { and maintain the identification, classification, acceleration and } \\
\text { evaluation }\end{array}$ \\
\hline $\begin{array}{l}\text { Vocational } \\
\text { routes }\end{array}$ & $\begin{array}{l}\text { Clarify the targets of future } \\
\text { career and the approaches to } \\
\text { reach these targets }\end{array}$ & $\begin{array}{l}\text { Offering professional guidance and consultation to gifted } \\
\text { individuals' interests, abilities and value } \\
\text { Optimizing tutorial system, probation, and vocational } \\
\text { experience and matching with students' interests and abilities }\end{array}$ \\
\hline \multirow{2}{*}{\multicolumn{3}{|c|}{ 3.6 Gifted education teachers' professional development }} \\
\hline & & \\
\hline & Output (students) & Evidence-based practice（gifted education teachers/educators） \\
\hline $\begin{array}{l}\text { Talent } \\
\text { exploitation }\end{array}$ & $\begin{array}{l}\text { Interacting with teachers } \\
\text { who obtain the } \\
\text { qualification of gifted } \\
\text { education }\end{array}$ & $\begin{array}{l}\text { Systematically joining in continuous, research-based professional } \\
\text { development trainings; comprehending the characteristics, } \\
\text { evaluation, curriculum planning, learning environment of gifted } \\
\text { education and learning how to exploit surroundings and teaching } \\
\text { activities; taking part in persistent design of professional } \\
\text { development, such as anti-intellectualism and impartial gifted } \\
\text { education; obtaining human resource, and financial support, and } \\
\text { joining in gifted education organizations }\end{array}$ \\
\hline $\begin{array}{l}\text { Development } \\
\text { of social } \\
\text { emotion }\end{array}$ & $\begin{array}{l}\text { Rapid development in } \\
\text { social and emotional } \\
\text { aspects }\end{array}$ & $\begin{array}{l}\text { Taking part in persistent professional development to support gifted } \\
\text { individuals social and emotional demands }\end{array}$ \\
\hline $\begin{array}{l}\text { Lifelong } \\
\text { learning }\end{array}$ & $\begin{array}{l}\text { Process of accompanying } \\
\text { educators' lifelong } \\
\text { learning and exploit their } \\
\text { own talents and } \\
\text { potentials }\end{array}$ & $\begin{array}{l}\text { Obtaining teaching practice and professional development } \\
\text { opportunities in schools, professional organizations and higher level } \\
\text { educational institutions; taking part in persistent professional } \\
\text { development, including regular follow-up plans, finding evidence } \\
\text { through teaching practice and students' learning activities; applying } \\
\text { multi-professional development models (online courses, workshops, } \\
\text { and professional learning communities) }\end{array}$ \\
\hline $\begin{array}{l}\text { Moral } \\
\text { principles }\end{array}$ & $\begin{array}{l}\text { Developing talents under } \\
\text { the ethics of educators }\end{array}$ & $\begin{array}{l}\text { Demonstrating cultural and their own reference standards when } \\
\text { cultivating gifted individuals; observing the rules, policies and } \\
\text { standards of ethic practice }\end{array}$ \\
\hline
\end{tabular}

\section{Enlightens}


In the traditional view, the standards of judging the quality of gifted education programs include theoretical frameworks, practical models, operational processes, supporting funds, conclusions and suggestions, effects and influences, and etc. In the United States, gifted education outputs are regarded as the only standard of program evaluation, which emphasizes on the gains and changes in the programs and the practice devoted by teachers and other educators, without the influence of discourse hegemony, obscure artificial operation, but the procedures and activities operated by teachers based on the demands and targets of gifted education. All of the procedures and activities are observable, operable, and could provide sufficient evidence for programs evaluation.

\subsection{Professional development road is required by gifted education teachers}

Not like mainstream teachers, except theoretical attainment and practical experience, gifted education teachers should not only master the skills of authentication, selection, cultivation, and evaluation, but also professionalized understanding to their identity, as well as the profound understanding towards their own professional spirits, duties, attainments, developments, prospects and etc. Currently, there is very limited studies directly concerning the typical characteristics of gifted education teachers, nor enough evidence to demonstrate whether teachers themselves should have giftedness, specific knowledge and skills, special educational backgrounds, and special trainings. National Standards in Gifted and Talented Education in 2006 underlines that teachers should enhance the preparation on understanding giftedness, learning environment, curriculum knowledge, evaluation, teaching instruction, ethics, cooperation and sharing. The teachers not only require the resources and conditions as ordinary teachers have, but also need the special professional development road as the mentors of gifted students.

\subsection{The principle of equity should be insisted in gifted education}

Unquestionably, gifted individuals come from various classes, cultures, races and backgrounds. However, there is very limited number of them selected from disadvantaged groups in economy, minorities, and groups with disabilities. The main cause is the bias of standardized tests, selective recommendation from teachers and schools, and stereotyped ideas that no gifted individual could come from these groups. As a matter of fact, many extraordinary achievements have been created by the so-called "minorities". Study showed that African-American gifted individuals achievements preceded average gifted ones. Female gifted individuals could have outstanding achievements as males in math, physics, science, medicine, and legislation, which are traditionally predominated by males. ${ }^{[12]}$ If identifying and selecting opportunities are not provided to those "minorities", nor the conditions offered to transform giftedness into achievements, a country will lose a portion of resources of talents. In addition, another opinion should be clarified that equality doesn't mean egalitarianism. Providing individualized and special services doesn't concern the educational injustices of occupying public resources to satisfy personal needs. Rather, on the contrary, it is an implementation of differential equality through confronting, respecting and developing difference as criterion. The real educational equality is not stereotyped egalitarianism, but the coexistence of general education and gifted education.

\subsection{Family is the cradle of gifted education}

Many studies showed that children's development and achievement is closely connected with their families. Every family provides unique and mini cultural space to their children, which also create the conditions for the appearance of gifted individuals. Unfortunately, there has been no finding demonstrating what kind of family will create gifted children. ${ }^{[13]}$ However, accumulative effects of family's attitude on high achievements can influence the development of giftedness. ${ }^{[14]}$ This has become the perfect excuse for those who have fontal bias against giftedness selection. Heredity from parents and the familial environment establish the foundation of the birth of gifted individuals. At the same time, from the objective and impartial view, teachers should be good at finding the potential gifted ones from different family background in order to avoid the vanishing of talents out of the negligence on giftedness.

ISSN: 0010-8189 


\subsection{Improving evaluation and supporting system of gifted education}

Without standards, government cannot get the basis to run wide-range of evaluation and educational accountability. Gifted education teachers will lose the reliance of scientifically selecting, cultivating and evaluating gifted individuals. What's worse, educational appropriation and the fundaments of teachers' professional development will also be affected. From the experience of American gifted education, standards should contain gifted children selection, curriculum and teaching, project evaluation, gifted education teachers' professional development. Meanwhile, laws and policies should be formulated at the national level. It is very necessary to enhance the legislative construction on gifted education, exploit related educational resources and techniques, develop think tanks constituted by gifted groups, and provide research and academic material conditions, working environment and emotional support to them.

4.6 Positively exploiting programs and tap gifted individuals' potential

China is never lack of talents both in history and at present. However, compared with developed countries, the research on gifted education in China has seriously lagged behind and couldn't match the developing demands of era. Since 1978, special class for the gifted students has been established in the University of Science and Technology of China (USYC). In a sense, it is a long term project to identify, study and cultivate gifted individuals. "15]" Soaring Plan" launched in Beijing, 2008, "Top Talent Training Program for Middle School Students" in Shanghai, 2010, "Program Bamboo Shoots in Spring" in Shaanxi Province, and "Rising Sun Plan" in Tianjin are all valuable attempts of gifted education in recent years. At the same time, idea of gifted education in China has been gradually changed as from emphasizing equation to equality and excellence, from elite education to exploiting talents of all, from occasional fragmented cultivation to systematic and comprehensive education. ${ }^{[16]}$ Research focus has been turn to cultural diversity, talent fragmentary, ecological planning, and the function of gifted education in educational reform.

\subsection{Investment on gifted education will receive long term returns}

Gifted education expends an abundant of resource but with inconspicuous fruit. It seems not very matching the Utilitarian short term returns. Therefore, state governments and schools in the United States make negative coping, even pay no attention at all. In 2013, 14 states put 0 efforts in their gifted education, while only 9 states offering supporting policies. It follows that gifted education has been put into an awkward situation. However, if China abandons or neglects gifted education for no reason, the results would be horrible. Not only the talents and giftedness are crucially trampled, but also causes the outflow of gifted people. Eventually, national creativity will be weakened and the international competitiveness will also be seriously damaged. Therefore, gifted education should be a great and promising journey. Any country, which makes efforts on this field, will definitely occupy the highland of human resource, and harvest long term returns.

Gifted individuals are the welfare of a country. ${ }^{[17]}$ It is to be cherished.

\section{Acknowledgements}

This research was supported by 2020 Key Project of the Chinese 13th Five-Year Plan for National Education and Science (Grant No. DHA200323).

\section{References}

[1] L.K. Miller. "The savant syndrome: intellectual impairment and exceptional skill," Journal of Psychological Bulletin, vol. 125, no. 1, pp. 31-46, 1999.

[2] C.W. Taylor. "Cultivating simultaneous student growth in both multiple creative talents and knowledge,"

ISSN: 0010-8189 
In: Renzulli, J. S. (Ed.), Systems and Models for Developing Programs for the Gifted and Talented.” Mansfield Center, CT: Creative Learning Press, 1986, pp. 306-351.

[3] M. Snyderman, S. Rothman. "Survey of expert opinion on intelligence and aptitude testing," Journal of American Psychologist, no. 42, pp. 31-46, 1987.

[4] Z. Albert, A.H. Kurt. "Conceptions of Giftedness from a meta-theoretical perspective from international handbook of giftedness and talent," New York: Elsevier Press, 2000, pp. 1.

[5] R. E. Snow, D. F. Lohman. "Toward a theory of cognitive aptitude for learning from instruction," Journal of Educational Psychology, no. 76, pp. 347-376, 1984.

[6] M.U.M. Gross. "Nurturing the talents of exceptionally gifted individuals," In: Heller, K. A. Monks, F. J. and Passow, A. H. (Eds), International Handbook of Research and Development of Gifiedness and Talent, Oxford: Pergamon Press, 1993, pp. 473-490.

[7] H.L. Swanson. "The role of working memory and dynamic assessment in the classification of children with learning Disabilities," Journal of Learning Disabilities Research \& Practice, vol. 9, no. 4, pp. 190-202, 1994.

[8] D. K. Simonton. “Gifted child, genius adult: three life-span developmental persepctives,” In: Friedman, R. C.Rogers, K. B. (Eds), Talent in Context: Historical and Social Perspectives on Giftedness, Washington, DC, American Psychological Association Press, 1998, pp. 151-175.

[9] J.F. Feldhusen, A. Robinson. "The purdue secondary model for gifted and talented education," In: Renzulli, J. S. (Ed.), Systems and Models for Developing Programs for the Gifted and Talented, Mansfield Center, CT, Creative Learning Press, 1986, pp. 153-179.

[10] M.N. Bruce-Davis, E.J. Gubbins, C.M. Gilson, et al., "STEM high school administrators, teachers, and students' perceptions of curricular and instructional strategies and practices," Journal of Advanced Academics, no. 25, pp. 272-306, 2014.

[11] J.H. Borland, "The construct of giftedness," Peabody Journal of Education, no. 25, pp. 72, 1997.

[12] P. Campbell, B.C. Clewell. "Science, maths, and girls: still a long way to go," Journal of Education Week,vol. 9, no. 15, pp. 50-51, 1999.

[13] D.K. Simonton. "Gifted child, genius adult: three lifespan developmental perspectives," In: Freidman, R.Rogers, K. B. (Eds.) Talent in Context: Historical and Social Perspectives on Giftedness, Washington, American Psychological Association Press, 1998, pp. 151-175.

[14] C.H. Perleth, K. Heller. "The munich longitudinal study of giftedness,” In: Subotnik, R. F. Arnold, K. D. (Eds), Beyond Terman: Contemporary Longitudinal Studies of Giftedness and Talent, Norwood, NJ: Ablex Press, 1994, pp. 77-114.

[15] Z. Zha. "Programs and practices for identifying and nurturing giftedness and talent in the People's Republic of China," In: Heller, K. A. Mönks, F. J. Passow, A. H. (Eds.), International Handbook of Research and Development of Giftedness and Talent, Oxford: Pergamon Press, 1993, pp. 809-814.

[16] W.T. Wu. "Thinking globally, acting locally-the development and perspectives of gifted education in Chinese," In: Special Education Association, R. O. C. (Ed.), Proceedings of the Symposium for the 25th Anniversary of Gifted Education in Taiwan, R. O. C, Taipei, Taiwan: NTNU Press, 1998, pp. 19-39.

[17] R.S. Persson. "High ability, society and its future: the broader curriculum," Australasian Journal of Gifted Education, vol. 8, no. 1, pp. 5-14. 